\title{
Prototype of Science Literacy Instruments on the Competence of Construction and Property Technology Expertise
}

\author{
Faruq Abdur Rouf ${ }^{1 *}$, Riyan Arthur ${ }^{2}$, Daryati $^{3}$, Arris Maulana ${ }^{4}$ \\ ${ }^{1,2,3,4}$ Faculty of Engineering, State University of Jakarta, Indonesia \\ *Corresponding author. Email: faruqabdurrouf1517817004@mhs.unj.ac.id
}

\begin{abstract}
ABSTARCT
This study aims to develop a prototype of a mechanical scientific literacy instrument for vocational students on the competence of construction technology and property expertise. The type of research used in this research is the Research and Development method (R\&D). This research was conducted from January to February 2020. Based on expert judgment, this scientific literacy instrument can be said to be fit for use both in content and construction.
\end{abstract}

Keywords: Science Literacy, Instrument, Mechanical, Vocational Student.

\section{INTRODUCTION}

Literacy among Vocational High School (SMK) students is important to note as a form of responsibility for the advancement of vocational education. OECD Survey 5 The last period shows very low literacy skills of students [1]. The latest OECD results for 2018 were to take a sample of junior high school students. This means that between years, students are at the NEXT level, especially SMK. This apprehensive condition is certainly a challenge for vocational education. Therefore, it is necessary to build a measurement system and pattern to detect the literacy skills of students who enter the next level. [2]. This is necessary for the appropriate action and treatment of the target and according to the student's circumstances in general [3].

The problem of arranging and developing instruments is that they must be able to build concepts and indicators that have good reliability [4]-[6]. As is well known, the reference and conceptual standards differ in each country in measuring their abilities, skills, competencies, and professions [7]-[9]. Scientific literacy is one of the main components that underlie competency in engineering-based SMKs, especially in construction and property expertise programs. In addition, to improve language skills, scientific literacy is also closely related to the functional use of technology [10], [11] and to give attention to the living environment [12], [13]. Such an important coverage considering the focus of SMK focused on the applied domain, functional [14], [15] Moreover, there are not many researchers who pay particular attention to the science literacy of this vocational field.

To determine the progress of learning scientific literacy, vocational school students need a reference or benchmark to be able to know the progress obtained from each process carried out [16], [17]. As outlined above, it takes concepts, indicators and instruments so that these capabilities can be measured clearly, reliably and consistently [18]-[21]. Therefore, the science concept referred to by science literacy vocational students refers to subjects closely related to science, namely mechanical engineering, where the material is derived from physics and chemistry science [22]-[24] On the previous level (SMP).

Science literacy can be interpreted from two large viewpoints that all refer to science education experts. The first view is more scientific and focused on science as a subject, thus placing science as an institution with language as the presenter in the formation of science literacy [25]. The second view sees science literacy as a functional science with a heavy point in the achievement of science objectives. That is, science can "infiltrate" the various joints of everyday life, from the life of individuals, families to the world, and the surrounding environment [26]. Both views on science 
literacy are not contradictory, instead of strengthening each other. It can be seen clearly in the realm of vocational education, where mechanics as a science should be able to integrate with the subjects of concrete construction, steel, roads, and bridges [27], [28]. They then produce real work that is the purpose of the Skills program in SMK building construction both in the form of drawings, planning and construction products.

The difference in the combination of literacy that refers to "written reading material" and which refers to the ability to read the situation and the current condition of the experts to be interesting when handed down on the realm of SMK. As well as the view of science as science and scientific view as a way of achieving life objectives [29] No less complicated when entering the realm of vocational education. Education focused on functional and applied work is proper to focus on human development attention based on science and technology [30]. That is, the two views have become a whole unity if we talk about vocational education or vocational in Indonesia.

Science literacy is not only related to reading, writing, and communicating about science [31]. Moreover, science literacy is the basis of critical thinking skills [32] and decision making [33]. Science literacy consists of content knowledge, understanding of scientific practices and understanding of science as a social process [34]-[36].

Scientific literacy is not only overly discussed at the individual level but also at the group and community level. Therefore, this study is limited to the level of the individual concerned. Individual discussions will be focused on vocational students' scientific literacy which consists of material, context, and process [37], [38]. The scope of the material covered is to implement and analyses the conceptual knowledge of structural elements, design and, load on the expertise competence of building information modeling (DPIB) [39].

\section{METHOD}

The method used in this research is the development of instruments that refer to The Borg and Galls's model
[40]. The stages of research that has been prepared the five stages should be described, However, this research is limited only to the preparation of a prototype to be validated by experts in the field of engineering mechanics instruments. The grid and grain was developed referring to the 2016 spectrum of vocational skills for DPIB expertise issued by the Ministry of Education and Culture (Kemdikbud RI). The data analysis technique used descriptive statistics and the Aiken-V consistency test. The measurement criteria for the prototype of this tool consist of the contents of mechanical mechanics and test construction in accordance with the concept of scientific literacy using a Likert scale (1-5). Descriptive analysis with the following criteria:

Table 1. Descriptive Product Assessment Criteria (\%)

\begin{tabular}{|l|l|}
\hline Average Score & Category \\
\hline $80-100$ & Very Feasible \\
\hline $66-79$ & Feasible \\
\hline $56-65$ & Fairly Feasible \\
\hline $40-55$ & Less Feasible \\
\hline$<40 \%$ & Not Feasible \\
\hline
\end{tabular}

\section{RESULT \& DISCUSSION}

The development of this prototype started from the development of the instrument grid with material taken from the competency of SMK Year 2016 DPIB competence, understanding of structural elements, understanding the style of the building structure, influencing factors affecting the building structure based on design criteria, analyzing the style on simple frame construction, analyzing the inner styles on simple beam construction and analyzing the balance of style on simple beam.

Furthermore, the material was developed by elaborating the dimensions of science literature consisting of content, context and process. The arrangement of the lattice also pays attention to the domain aspects of cognitive implementation (C3), analysis/Synthesis (C4) and Evaluation (C5) with a focus on the dimension of conceptual knowledge in the preparation of its instrument. The instrumentation grids are as table 2 follows:

Table 2. Instrument Grids Science literate mechanics Engineering SMK DPIB

\begin{tabular}{|c|c|c|c|}
\hline No. & Science Literacy Indicators & Sub Indicators & $\begin{array}{l}\text { Item } \\
\text { Number }\end{array}$ \\
\hline \multirow{3}{*}{1} & \multirow{3}{*}{$\begin{array}{l}\text { Recognizing and analyzing the use of } \\
\text { research methods }\end{array}$} & Identifying Valid Scientific arguments & 1,4 \\
\hline & & Evaluating the validity of a knowledge source & 5,8 \\
\hline & & Evaluating the use of scientific information & 10,13 \\
\hline \multirow{3}{*}{2} & \multirow{3}{*}{$\begin{array}{l}\text { Organizing, analyzing and interpreting data } \\
\text { related to scientific information }\end{array}$} & Analyzing graphical data representation & 3,6 \\
\hline & & Interpret the data graphically & 7,12 \\
\hline & & Solve problems using quantitative abilities & 16,17 \\
\hline 3 & & scientific knowledge appropriately & $2,9,11$ \\
\hline
\end{tabular}




\begin{tabular}{|c|l|l|c|}
\hline \multirow{2}{*}{ No. } & Science Literacy Indicators & Sub Indicators & $\begin{array}{c}\text { Item } \\
\text { Number }\end{array}$ \\
\hline \multirow{2}{*}{$\begin{array}{l}\text { Explain the phenomenon scientifically, } \\
\text { namely, to recognize, provide, and evaluate } \\
\text { explanations about various natural } \\
\text { phenomena and technologies }\end{array}$} & Produce a model/picture that is describing & 15,14 \\
\cline { 2 - 4 } & Make predictions/give reasons appropriately & 18,19 \\
\hline
\end{tabular}

The grid above is a result of the elaboration of material mechanics, the cognitive sphere, and knowledge that is further developed based on the concept of science literacy. Based on the grid above, then the composition of the instrument is done following the concept of science literacy techniques mechanics. One form of grain developed as follows:

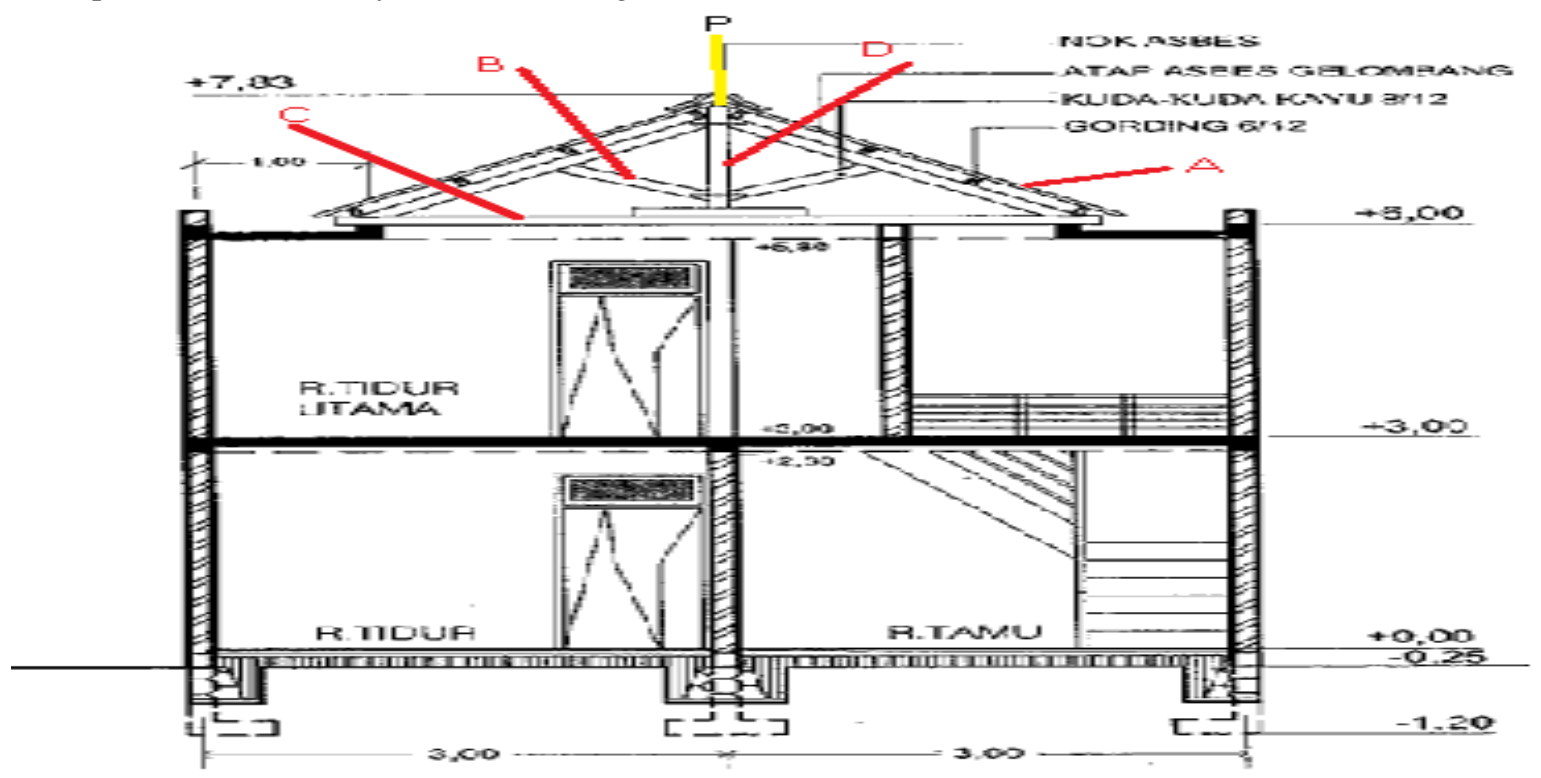

Figure 1 Form of grain

Above you can see a simple house structure image. One of the most important parts of the building above is the easel. The truss frame construction is a frame arrangement that functions to support the weight of the roof including its own weight and at the same time can give shape to the roof. The truss frame is the main support for the roof structure. This structure is included in the classification of the frame structure (truss). Generally, the horses are made of wood, bamboo, steel and reinforced concrete. Basically, the frame construction consists of a series of rods that always form a triangle. Taking into account the weight of the roof as well as the material and shape of the cover, the frame construction will be different from one another, however, each frame arrangement must be a single solid form that can later support the work. load without changing.

Figure 1 shows the red lines, the red lines are parts of the horses which consist of (A) Gording or stance legs; (B) is called a push beam which serves to prevent flexing of the stance's legs; (C) It is called a flexible beam or pull rod which functions to prevent the legs of the horses from moving and part (D) is called a hanger which functions to prevent a drop in the pull rod.
Question:

1. In Figure 1, what would happen if parts B, C and D were removed?

A. The stance's legs will drop and move sideways and press against the wall

B. The stances will rise under the pressure from the wall

C. The stance's feet will move inward and lose their support

D. The horses will become stronger

2. In the structure of the easel. The larger the stretch of the house the greater the possibility of the easel's legs flexing.

The overall science literacy instrument is a 19-grain technique that is then validated by 3 experts in the field of mechanical content and 3 experts in the field of Science literacy instrument construction [42]. As has been recomposed above, that this validation uses a scale of consent from experts covering 5 ranges (Likert). The results are as follows: 
Table 3. Content expert validation results and test grain construction (\%)

\begin{tabular}{|l|c|c|}
\hline \multicolumn{1}{|c|}{ Indicator } & \multicolumn{2}{c|}{ Percentage } \\
\cline { 2 - 3 } & Content & Construction \\
\hline Recognizing and analyzing the use of research methods & 88,89 & 81,11 \\
\hline $\begin{array}{l}\text { Organizing, analyzing and interpreting data related to scientific } \\
\text { information }\end{array}$ & 91,11 & 78,09 \\
\hline $\begin{array}{l}\text { Explain the phenomenon scientifically, namely, to recognize, provide, } \\
\text { and evaluate explanations about various natural phenomena and } \\
\text { technologies }\end{array}$ & 90,48 & 78,25 \\
\hline Total & 90,16 & \\
\hline
\end{tabular}

Based on expert validation results, it can be explained that for indicators recognizing and analyzing the use of research methods obtained average mechanics material score of $88.89 \%$ in highly viable categories and from the construction side of grain literacy of $75,56 \%$ in eligible categories. In organizing indicators, analyzing and interpreting data related to scientific information is obtained an average score of $91.11 \%$ for the material and $81.11 \%$ for literacy construction which both belong to very decent categories. The indicator explains the scientific phenomenon, namely recognizing, providing, and evaluating explanations of various natural phenomena and technology gained an average score of $90.84 \%$ which is very decent for engineering mechanics material and $78.09 \%$ for science literacy construction in decent categories. These results indicate both material and science literacy construction, this prototype can be categorized worthy.

If all expert assessments are analyzed descriptively, the results will not be much different. An average score of $90.16 \%$ which is very well worth reviewing of the mechanics material and an average score of $78.25 \%$ that deserves the second science literacy item construction is still in the decent category. That is, the whole item can be said to be worth using to measure science literacy techniques of mechanics.

To measure the consistency made by all three experts, further analysis is required using Aiken-V. The results of each expert validation both the material mechanics and the construction of science literacy items can be presented as follow

Table 4. Results of the analysis of Aiken-V material expert and the construction of Science literacy

\begin{tabular}{|l|c|c|}
\hline \multirow{2}{*}{\multicolumn{1}{|c|}{ Indicator }} & \multicolumn{2}{c|}{ Aiken-V } \\
\cline { 2 - 3 } & $\begin{array}{c}\text { Material of } \\
\text { Mechanic }\end{array}$ & $\begin{array}{c}\text { Grain } \\
\text { Construction }\end{array}$ \\
\hline Recognizing and analyzing the use of research methods & 0,861 & 0,694 \\
\hline $\begin{array}{l}\text { Organizing, analyzing and interpreting data related to scientific } \\
\text { information }\end{array}$ & 0,889 & 0,764 \\
\hline $\begin{array}{l}\text { Explain the phenomenon scientifically, namely, to recognize, provide, and } \\
\text { evaluate explanations about various natural phenomena and } \\
\text { technologies }\end{array}$ & & \\
\hline Total & 0,881 & 0,726 \\
\hline
\end{tabular}

Calculations in the coefficient of Aiken $\mathrm{V}$ can be interpreted as a consistent awarding of the three validators of an item or an assessed object. As for the criticism is that the scoring can be said to be consistent by the validator if the Aiken $\mathrm{V}$ coefficient is above 0.600. [43] The table above shows that in measuring the material in all indicators the validator has a good consistency because it is all in the can coefficient above 0.600. Similarly, in scoring for the items measuring indicators of science literacy are reviewed from the construction of the grain, all of which have a coefficient above 0.600 .

Based on the explanation above, the product that is a prototype of this instrument can be said to be feasible. This means that the instrument development phase can be resumed at a limited scale test that involves the students of SMK DPIB by the stage of development research method of Borg \& Gall. The test stages on a limited scale are the conformity and reliability tests of a product[40] (instrument).

The expert validation of the prototype instruments of science literacy techniques does produce instruments that can be said to be worthy of use. However, if it is further, there are things to be considered in this study, which is a well-established grain construction score with material results. The results showed that there are still some things that need to be fixed in the Science Literacy test item of this technique. Construction tests have a position that is not less important compared to the test material. Error in the destruction of the test, it will impact the measurement instability made even not a possible error in measurement [44]. 


\section{REFERENCES}

[1] OECD, OECD Multilingual Summaries PISA 2018 Results What Students Know and Can Do Hasil PISA 2018 (Volume I). Paris: OECD, 2019.

[2] C.-T. T. Wen et al., "Students' guided inquiry with simulation and its relation to school science achievement and scientific literacy," Comput. Educ., vol. 149, no. May, p. 103830, 2020.

[3] N. Allum, J. Besley, L. Gomez, and I. BruntonSmith, "Disparities in science literacy," Science (80-. )., vol. 360, no. 6391, pp. 861-862, 2018.

[4] R. Arthur, "Evaluasi Program Diklat Karya Tulis Ilmiah untuk Widyaiswara Pusbangtendik Kemdikbud," J. Penelit. dan Eval. Pendidik., vol. 22, no. 1, pp. 35-48, 2018.

[5] E. Winther and V. K. Klotz, "Measurement of vocational competences: An analysis of the structure and reliability of current assessment practices in economic domains," Empir. Res. Vocat. Educ. Train., vol. 5, no. 1, pp. 1-12, 2013.

[6] F. Achtenhagen and E. Winther, "Workplacebased competence measurement: Developing innovative assessment systems for tomorrow's vet programmes," J. Vocat. Educ. Train., vol. 66, no. 3, pp. 281-295, 2014.

[7] A. Rokhmah, W. Sunarno, and M. Masykuri, "Science Literacy Indicators in Optical Instruments of Highschool Physics Textbooks Chapter," J. Pendidik. Fis. Indones., vol. 13, no. 1, pp. 19-24, 2017.

[8] A. Rusilowati, L. Kurniawati, S. E. Nugroho, and A. Widiyatmoko, "Developing an instrument of scientific literacy asessment on the cycle theme," Int. J. Environ. Sci. Educ., vol. 11, no. 12, pp. 5718-5727, 2016.

[9] V. K. Klotz, S. Billett, and E. Winther, "Promoting workforce excellence: Formation and relevance of vocational identity for vocational educational training," Empir. Res. Vocat. Educ. Train., vol. 6, no. 1, pp. 1-20, 2014.

[10] J. Gropen, J. F. Kook, C. Hoisington, and N. ClarkChiarelli, "Foundations of Science Literacy: Efficacy of a Preschool Professional Development Program in Science on Classroom Instruction, Teachers' Pedagogical Content Knowledge, and Children's Observations and Predictions," Early Educ. Dev., vol. 28, no. 5, pp. 607-631, 2017.

[11] S. Techakosit and P. Wannapiroon, "Connectivism Learning Environment in Augmented Reality Science Laboratory to Enhance Scientific Literacy," in INTE 2014, 2015, vol. 174, pp. 2108-
2115.

[12] F. Alivernini and S. Manganelli, "Country, School and Students Factors Associated with Extreme Levels of Science Literacy Across 25 Countries," Int. J. Sci. Educ., vol. 37, no. 12, pp. 1992-2012, 2015.

[13] K. A. Lawless et al., "Promoting students' science literacy skills through a simulation of international negotiations: The GlobalEd 2 Project," Comput. Human Behav., vol. 78, no. January, pp. 389-396, 2018.

[14] S. Sutjipto, "Perancangan Kurikulum Sekolah Menengah Kejuruan Sebagai Pranata Budaya Kerja," J. Pendidik. dan Kebud., vol. 4, no. 1, pp. 102-126, 2019.

[15]D. Leutner, J. Fleischer, and J. Grünkorn, Competence Assessment in Education, vol. 40, no. 3. cham: Springer International Publishing, 2017.

[16] Sugiyanto, M. Wena, and Isnandar, "Developing Learning Materials Based On Training Within Industry (TWI) To Improve The Building Construction Student's Learning Outcomes," J. lти Pendidik., vol. 24, no. 2, pp. 80-85, 2018.

[17] V. Deutscher and E. Winther, "Instructional sensitivity in vocational education," Learn. Instr., vol. 53, pp. 21-33, 2018.

[18]H. T. Prabowo, "Pengembangan instrumen evaluasi berbasis literasi sains untuk siswa smk," ASNA J. Kependidikan Islam dan Keagamaan, vol. 1, no. 2, pp. 57-71, 2019.

[19] M. E. Castellano, G. B. Richardson, K. Sundell, and J. R. Stone, "Preparing Students for College and Career in the United States: the Effects of Career-Themed Programs of Study on High School Performance," Vocat. Learn., vol. 10, no. 1, pp. 47-70, 2017.

[20] A. Taskiran et al., "Globalizing online learning: Exploring culture, corporate social responsibility, and domestic violence in an international classroom," E-Learning Digit. Media, vol. 16, no. 1, p. 103603, 2019.

[21]Z. Matondang, "Kompetensi Profesional Guru SMK Bidang Keahlian Teknik Bangunan di Medan," J. Pendidik. dan Kebud., vol. 16, no. 6, p. 638,2010

[22] V. Erofeev, "Frame Construction Composites for Buildings and Structures in Aggressive Environments," Procedia Eng., vol. 165, pp. 1444-1447, 2016.

[23] A. Dudung, "Pengaruh Model Pembelajaran dan Kemampuan Numerik Terhadap Hasil Belajar 
Permesinan dengan Mengontrol Potensi Keteknikan," J. Teknol. Pendidik., vol. 19, no. 3, pp. 156-174, 2017.

[24]Z. Ma and J. Ma, "Formulating the application functional requirements of a BIM-based collaboration platform to support IPD projects," KSCE J. Civ. Eng., vol. 21, no. 6, pp. 2011-2026, 2017.

[25]M. Bucchi and B. Saracino, "Visual Science Literacy': Images and Public Understanding of Science in the Digital Age," Sci. Commun., vol. 38, no. 6, pp. 812-819, 2016.

[26]E. Knain, Scientific Literacy for Participation. Rotterdam: Sense Publisher, 2015.

[27]R. Arthur, Y. Luthfiana, and S. Musalamah, "Analisa Kebutuhan Pengembangan Media Pembelajaran Pada Mata Kuliah Mekanika Bahan di Universitas Negeri Jakarta," J. Educ. Build., vol. 5, no. 2, pp. 38-44, 2019.

[28]M. D. Basito, R. Arthur, and D. Daryati, "Hubungan Efikasi Diri terhadap Kemampuan Berpikir Tingkat Tinggi Siswa SMK Program Keahlian Teknik Bangunan pada Mata Pelajaran Mekanika Teknik," J. Pensil, vol. 7, no. 1, pp. 114, 2018.

[29]E. Karademir and U. Ulucinar, "Examining the Relationship between Middle School Students' Critical Reading Skills, Science Literacy Skills and Attitudes: A Structural Equation Modeling," $J$. Educ. Sci. Environ. Heal., vol. 3, no. 1, pp. 29-29, 2016.

[30] S. S. Ho, A. D. Leong, J. Looi, L. Chen, N. Pang, and E. Tandoc, "Science Literacy or Value Predisposition? A Meta-Analysis of Factors Predicting Public Perceptions of Benefits, Risks, and Acceptance of Nuclear Energy," Environ. Commun., vol. 13, no. 4, pp. 457-471, 2019.

[31] C. Greenhow, T. Gibbins, and M. M. Menzer, "Rethinking scientific literacy out-of-school: Arguing science issues in a niche Facebook application," Comput. Human Behav., vol. 53, no. December, pp. 593-604, 2015.

[32] T. Chen, H. M. Hsu, S. W. Stamm, and R. Yeh,
"Creating an instrument for evaluating critical thinking apps for college students," E-Learning Digit. Media, vol. 16, no. 6, pp. 433-454, 2019.

[33]A. Crowell and C. Schunn, "Unpacking the Relationship Between Science Education and Applied Scientific Literacy," Res. Sci. Educ., vol. 46, no. 1, pp. 129-140, 2016.

[34] C. E. Snow and K. A. Dibner, Science literacy: Concepts, contexts, and consequences. Washington DC: The National Academies Press, 2016.

[35] N. Y. Hidayat, Wardono, and A. Rusilowati, "Analisis Kemampuan Literasi Matematika Ditinjau Dari Metakognisi Siswa dalam Pembelajaran Synectics Berbantuan Schoology," Prism. Prosicing Semin. Nas. Mat., vol. 2, pp. 911916, 2019.

[36] OECD, PISA 2018 insights and interpretations. Paris: OECD, 2019.

[37] R. Aisyah et al., "Learning Crude Oil by Using Scientific Literacy Comics," J. Phys. Conf. Ser., vol. 895, no. 1, pp. 1-7, 2017.

[38] E. Gebre, "Learning with multiple representations: Infographics as cognitive tools for authentic learning in science literacy," Can. J. Learn. Technol., vol. 44, no. 1, pp. 1-24, 2018.

[39] D. P. S. M. K. Kemdikbud, "Kompetensi Keahlian Desain Pemodelan dan Informasi Bangunan," 2016.

[40] W. R. Borg, M. D. Gall, J. P. Gall, and W. R. Borg, Educational Research, 7th ed. Boston: Pearson Education, Inc, 2003.

[41]S. Akbar, Instrumen Perangkat Pembelajaran. Jakarta: Remaja Rosdakarya, 2013.

[42] Djaali and P. Muljono, Pengukuran Dalam Bidang Pendidikan. Jakarta: Grasindo, 2008.

[43] S. Azwar, Reliabilitas dan validitas edisi 4. 2012.

[44] M. J. Kolen and R. L. Brennan, Statistics for Social and Behavioral Sciences Test Equating, Scaling , and Linking. New York: Springer International Publishing, 2014. 